\title{
STUDY OF THE RELATIONSHIP BETWEEN THE NUMBER OF TRAVELERS AND BEACH SERVICES IN SPAIN
}

\author{
JUAN IGNACIO GISBERT, ANTONIO PALAZÓN, ISABEL LÓPEZ, \\ LUIS ARAGONÉS \& YOLANDA VILLACAMPA \\ University of Alicante, Spain
}

\begin{abstract}
Spain has traditionally been a country where the coast and beaches have acted as raw material to develop the current tourism industry. This has always led diverse scale works and coastal transformations by Public Administrations in order to satisfy tourist needs and striving to attract a greater number of travelers. However, little and less is known about the objective impact on tourism reached by the final coastal typologies taken as a lot, rather than as a specific singular milestone. Therefore, this work has carried out a study of the 24 coastal provinces of Spain, using 31 variables to analyze the characteristics of 3,470 beaches along $1,905 \mathrm{~km}$ of Spanish coastline, to subsequently compare the obtained data with the average number of travelers of each province, in order to search for correlations indexes $\left(\mathrm{R}^{2}\right)$ that may show tourist behavior patterns according to the variables analyzed. Starting from an initial analysis in absolute terms with low correlation rates, it can be seen that trends vary if Spain is divided into four different geographical areas, North, East, South and islands, showing significantly different correlation rates according to beach types, meteorology, and services in each location. The studied correlations show a great geographical segmentation in the concerns of tourists and may serve as a guide for public and private entities to have objective criteria to establish regeneration typologies in coastal works, based on the desired result concerning tourism and sustainability. It may also reveal that some present and past actions, like regenerating gravel beaches using sand, that pursued this same objective share no relationship with tourism according to this study. Keywords: beach, travelers, tourism, beach services.
\end{abstract}

\section{INTRODUCTION}

Tourism as economic activity began its expansion after World War II due to the combination of several factors: overall economic development, improved social and labor (paid leave) conditions and infrastructure developments [1]. In the case of Spain, this development took place in the 1960s, linked to the "sun and beach" tourism. Regarding this model beaches became one more asset at the environmental and socioeconomic productive chain, and it was calculated, in terms of profitability that $1 \mathrm{~m}^{2}$ of dry beach could produce around 12,000€/year [2]. According to the World Tourism Organization (WTO), the expansion of the tourism phenomenon in recent decades will continue until it may become the most important commercial sector in the world.

Spain has taken advantage of this phenomenon by creating an industry of great importance in its economy. Proof of it is the growth of the impact that tourism generates in the Spanish GDP year after year, reaching in 2016 the figure of $16 \%$ after more than 75 million tourists visited the country (INE FRONTUR report).

This success is mainly based on ensuring an attractive, global and experiential offer to visitors, which must be equal to or greater than the alternative destinations that are presented to potential tourists [3], since tourism is an activity that is closely related to each one preferences and personal interests [4]. This implies that if the preferences of tourists are known, acts on the area can be taken in order to position it in the market in a preferential situation over others [5], or provide the services requested in order to make it as attractive as possible for the user. 
This adaptation to demand in a country that has traditionally offered "sun and beach", has ended up turning the coast and its beaches into the raw material which Spanish tourism industry has been built around, using these natural resources as the basis of its development and valuing them in terms of the use that society can make of them [1].

The socio-economic transformation that tourism has meant, has also led to several negative effects, such as environmental degradation of coastal dunes, low wetlands, beaches and their environment; as well as the overexploitation of huge amounts of water that aquifers have suffered to supply the cities in periods of droughts [6].

However, environmental awareness is growing worldwide, and it is generating a change in the attitude of consumers, who nowadays begin to opt for environmentally friendly products [7]. Hassan [8] indicated that destinations which get higher growth rates are those that establish environmental sustainability-oriented tourism strategies.

This paper seeks to determine which variables related to the type of beach, the services offered, and the weather properties are related to the number of travelers that come to the Spanish coasts, so that criteria with objective data can be established to act on seashores. To do this, statistical data from the National Statistics Institute will be used, as well as climatological data and a list of the services offered by each beach to determine its relationship with the influx of travelers.

\section{STUDIED AREA}

Spain has 24 coastal provinces (19 in the Iberian Peninsula, Illes Balears, Las Palmas, Tenerife and the autonomous cities of Ceuta and Melilla) that account for approximately one third of the country's surface, and in which $60 \%$ of the total population lives. This concentration in coastal provinces is largely due to the favorable climate conditions as well as a great economic development of coastal areas related to strictly maritime industries (ports, fishing, leisure, hospitality, etc.).

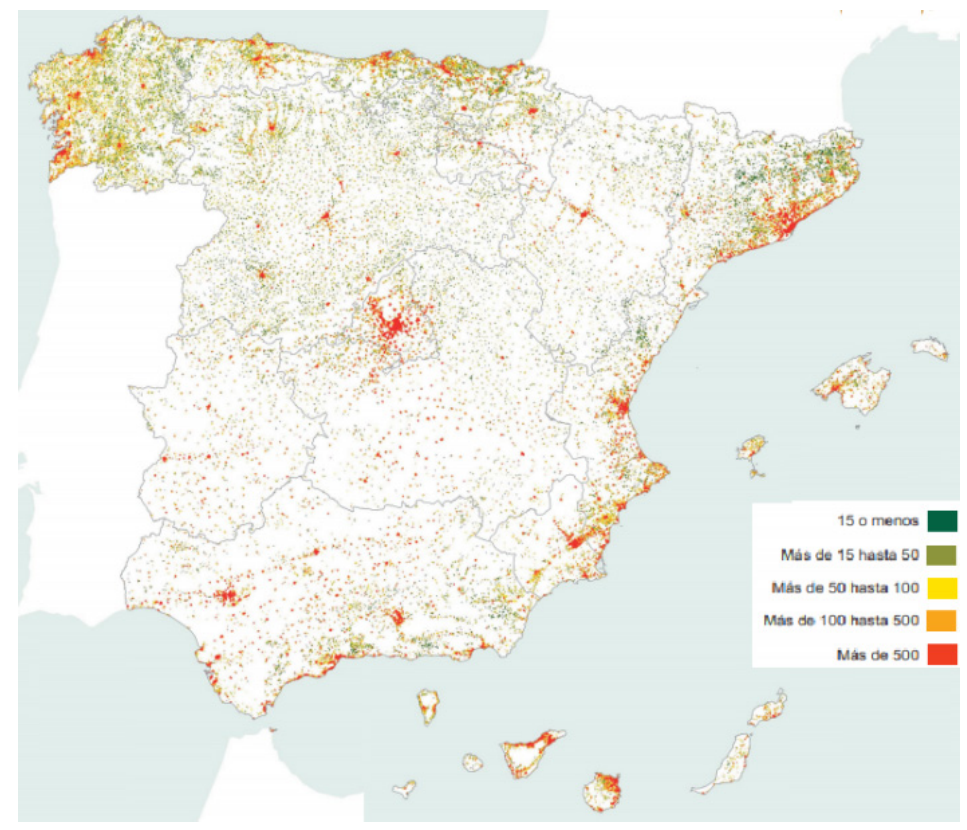

Figure 1: Population density (INE). 
Therefore, the study area is located along the beaches on the Spanish coastline, which constitutes a work area of about $1,905 \mathrm{~km}$ of seafront.

In the coastline analyzed, 3,470 beaches have been found with very different characteristics, from almost inaccessible cliffs to low sandy beaches with hard bottom sediment. This is largely due to the geographical diversity and the maritime characteristics of the different Spanish waterfronts, which include the Mediterranean Sea, the Atlantic Ocean and the Cantabrian Sea. This variety of circumstances, as well as the orography characteristics, generate a great coastal typological wealth that has its own characteristics in each analyzed area.

All these singularities have been analyzed individually on every beach in the Spanish coast, in order to perform a complete characterization of the coast and see its singularities altogether.

\section{METHODOLOGY}

To carry out this study and obtain the necessary information, direct sources have been used from each beach using satellite images. The characteristic data of coastal water has been obtained through climatic and meteorological sources, and statistical data of tourism through public governmental sources.

\subsection{Beach data}

Analysis of the Spanish coast beaches has been done through a compilation of satellite images of each coastal area, then analyzed using GIS methodology and elaborating worksheets with the characteristics of each beach.

For the study, a series of variables that affect the intrinsic characteristics of the beach have been considered, such as:

- Type of material (sand, gravel, rock or mixed)

- Grade of urbanization (urban, semi-urban or isolated)

Similarly, the existence (or not) of services that each beach presents to visitors have been analyzed, such as:

- Anchoring areas

- Access for the disabled

- Bus stops

- Parking

- Restrooms

- Feet showers

- Full showers

- Public phone

- Litter bins

- Cleaning service

- Sun beds rent

- Sun shades rent

- Nautic sports rent

- Tourism info

- Beach bars

- Kids area

- $\quad$ Sports area 


\subsection{Climatological data}

Data concerning climatic characteristics were obtained through public information from meteorological portals, information from Spanish government (MAPAMA), sea buoys and network data from state ports.

The indexes analyzed for the different provinces were:

- Sun radiation

- Sun hours

- Salinity

- Water temperature

\subsection{Travelers data}

Data concerning travelers were drawn from the National Institute of Statistics (INE), which has data discretized month by month of the number of travelers, both national and international, visiting each province.

The data analyzed were:

- Number of hotel beds

- Number of staff hired

- Number of Spanish travelers

- Number of international travelers

\subsection{Dependent and independent variables}

For the analysis, it was decided to establish the number of travelers as independent variable, leaving the rest as dependent variables. This involves a great disparity when analyzing each province, given that the number of beaches and their length are different in each case, and there are both quantitative and qualitative variables.

Since data travelers are only available per province, it was decided to establish as the unit for all variables the province to which every beach belongs, making a weighted average of each variable based on the length (in meters) of each sample unit.

Furthermore, to make the statistical analysis more representative for beach tourism, and to eliminate as much as possible city tourism, it was decided to take for the sample data only the months between May and September, peak periods of sun and beach tourism.

For this first analysis work, only the years 2015 and 2016 have been studied, since at the time the study began all the data referred to 2017 were not yet available.

The degree of affinity between the dependent and independent variables is set by the correlation coefficient $\mathrm{R}^{2}$.

\section{RESULTS}

To establish the variables related with the increase of traveler numbers, the dependent variables were crossed with the independent ones, obtaining the correlation coefficients as shown in Table 1.

As can be seen, there is hardly any correlation between independent and dependent variables except for the hotel rooms and staff, which is the most obvious relationship concerning tourism. It is surprising the large difference between the national tourism and international tourism in this aspect. 
Table 1: $\mathrm{R}^{2}$ coefficient between variables for all provinces.

\begin{tabular}{|c|c|c|c|c|}
\hline \multirow[b]{3}{*}{ Sand } & \multicolumn{4}{|c|}{ Travelers } \\
\hline & \multicolumn{2}{|c|}{ Spanish } & Foreigners & \multirow{2}{*}{$\begin{array}{l}\text { Total } \\
\quad 0,129\end{array}$} \\
\hline & & 0,363 & $0,070 \square$ & \\
\hline Mixt & 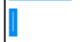 & 0,045 & 0,027 & 0,036 \\
\hline Urban \& Semi-urban & & b,551 口 & $0,107 \square$ & 0,198 \\
\hline Isolated & 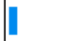 & 0,039 | & $0,018 \mid$ & 0,026 \\
\hline Sun Hours & $\mid$ & 0,009 【 & $0,050 \rrbracket$ & 0,048 \\
\hline Radiation & $\|$ & $0,015 \|$ & $0,004 \mid$ & 0,001 \\
\hline Water salinity & $\square$ & $0,112 \square$ & $0,157 \square$ & 0,178 \\
\hline Water temperature & ] & 0,077 口 & $0,096 \square$ & 0,111 \\
\hline Boat anchoring & 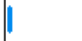 & $0,005 \|$ & $0,057 \|$ & 0,052 \\
\hline Acces for disabled & & 0,000 & $0,007 \mid$ & 0,005 \\
\hline Bus Stops & $\|$ & 0,011 & 0,000 & 0,000 \\
\hline Parking & | & $0,019 \mid$ & $0,009 \mid$ & 0,003 \\
\hline Restrooms & 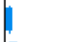 & 0,002 & 0,000 & 0,000 \\
\hline Feet showers & | & 0,046 【 & $0,058[$ & 0,067 \\
\hline Full Showers & & $0,000 \|$ & 0,001 & 0,001 \\
\hline Public telephone & 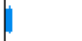 & 0,002 | & 0,029 | & 0,026 \\
\hline Litter Bins & 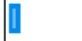 & 0,060 & 0,000 & 0,004 \\
\hline Cleaning Service & 1 & $0,060 \|$ & 0,001 & 0,000 \\
\hline Sunshade rent & $\square$ & $0,106 \square$ & $0,163 \square$ & 0,182 \\
\hline Sun beds rent & $\square$ & $0,240 \square$ & 0,252 & 0,300 \\
\hline Nautic sports rent & $\square$ & $0,179 \square$ & $0,153 \square$ & 0,190 \\
\hline Tourism info & $\square$ & 0,102 & $0,000 \mid$ & 0,003 \\
\hline Beach Bars & $\square$ & 0,278 & $0,038 \square$ & 0,080 \\
\hline Kids area & $\llbracket$ & $0,048 \mid$ & $0,011 \mid$ & 0,002 \\
\hline Sports area & $\square$ & $0,111 \mid$ & $0,001 \mid$ & 0,010 \\
\hline Hotel beds & $\square$ & 0,178 & 0,917 & 0,882 \\
\hline Staff number & $\square$ & 0,126 & 0,884 & 0,828 \\
\hline
\end{tabular}

Since Spain itself, as mentioned before, has several very different waterfronts, in order to search for correlations, the national geography has been divided into four areas, such as:

- $\quad$ East Front (from Gerona to Almería)

- South Front (from Granada to Huelva)

- North Front (from Pontevedra to Donostia)

- Islands (containing Illes Balears and the Canary Islands)

It should be noted that the province of Barcelona has been excluded from the Eastern Front due to the singularity of its urban tourism offer, which cannot be compared to the rest of the provinces in terms of sun and beach tourism.

As can be seen in Table 2, the relationship between the dependent variables and the number of travelers varies greatly depending on which area is being studied, regarding this, it can be deduced that:

\subsection{East Front}

In the East Front there is hardly any relationship between the beach typology, the weather, the services offered (except for the sun beds and sun shades renting), and the influx of travelers. 


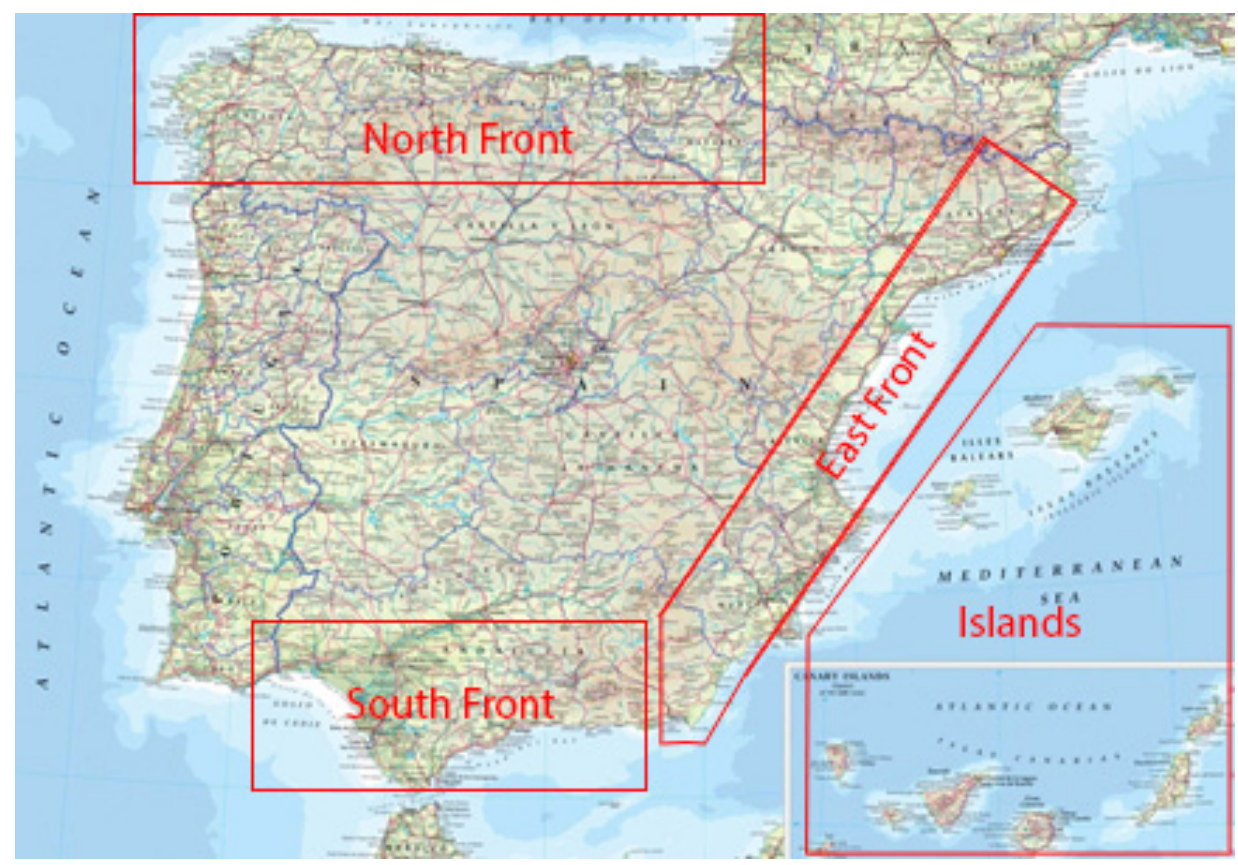

Figure 2: Area division.

This area has traditionally been a vacation spot due to its typological diversity of beaches and because of the weather, regardless of what it may offer. The results show that by not responding to any specific variable, it seems more an inertial tourism developed by tradition.

Most likely, the fact that the area has many second homes makes it may be a captive tourism, which makes a large number of travelers to remain as their chosen vacation destination.

\subsection{South Front}

For the South Front, the great correlation between the mixed beach typologies with the influx of international travelers stands out, being lower for the national ones. Also, the degree of urbanization interest is a primary factor to choose destination, although it is even greater for national tourism.

Regarding services, there is a strong correlation in the rental of sun beds, sun shades and water sports equipment. The existence of anchoring points is revealed as an important factor for foreign tourism, and the existence of beach bars, bus stops and parking areas for national tourism.

\subsection{North Front}

The North Front stands out for the low correlations that exist between almost any variable and foreign tourists, revealing itself as a mainly national destination. It can be seen in the strong correlation between the staff and the hotel beds with the national tourists.

In this regard, it seems that the Spanish tourist prefers slightly the mixed beaches to those of sand, and the isolated areas to the urbanized ones. 


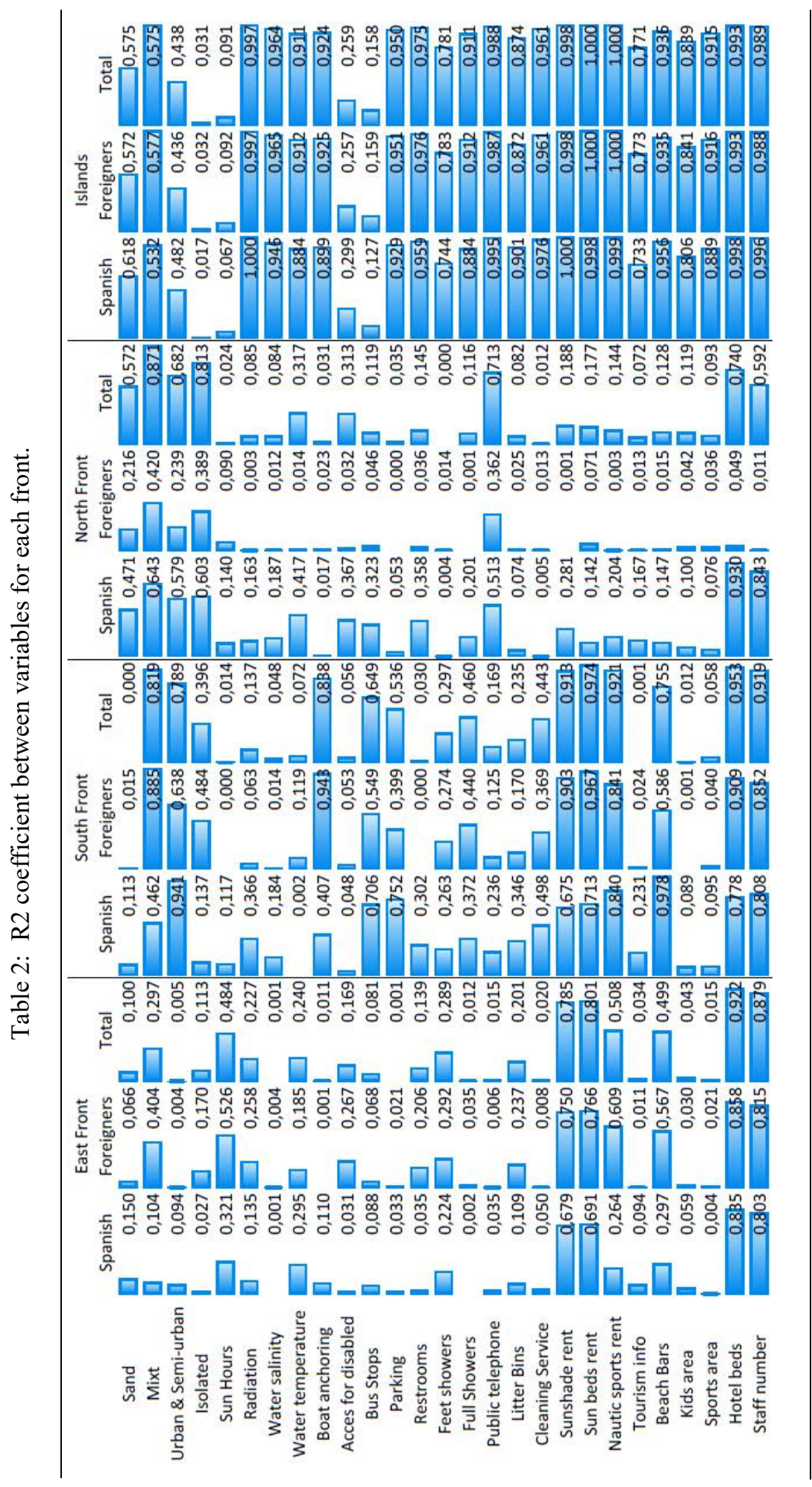




\subsection{Islands}

Concerning the islands, Canary and Balears, although the beach typology can be understood as indifferent to the tourist in general, there is a huge correlation between practically all the services and the number of travelers.

Similarly, it is seen that the climatic characteristics of the islands are a clear claim for tourism, despite the other fronts. Also, the great equipment and beach services available and its relationship with the influx of tourists is remarkable.

\section{DISCUSSION}

Due to the wealth generated by the coast, and the direct (public concessions) and indirect revenues (work, taxes, local development, etc.) produced by tourism, municipalities and public administrations have strived to give tourists what they may look for, generating transformations in the coastline by imitating models that have worked in certain areas. However, these transformations have often been based on arbitrary criteria, seeking to attract tourists under the belief that the same premises work everywhere equally. Proof of this is the lack of correlations that exist in a tourism area as traditional as the East of Spain, historically linked to urban beaches with services, and yet, according to data analyzed (Table 2), these variables are not related at all with the number of travelers.

Similarly, the present study reveals that the traditional image of sandy beaches is not necessarily linked to a greater tourist influx, so a reflection may be needed around some present and past works that has generated sandy beaches in historical areas of gravel and rocks [9], making great damage to the environment of some areas.

However, other aspects largely criticized due to the invasion of public space, such as beach bars, are revealed as a great attraction for national tourism in the South Front and the islands, while it has hardly any significance in the North and the East. This should conduce to a discussion around how to make these kinds of structures environmental-friendly, as it has a great concern with tourists.

Regarding this, the data analyzed shows that the over-urbanization in the eastern part of Spain, which has traditionally sought a massive tourist attraction, is not a factor that is related to the number of travelers (Table 2).

Therefore, it is important to reflect on the suitability that the tourist destination must be sustainable, not only economically, but also ecologically, socially, culturally and politically to be truly competitive [10].

\section{CONCLUSIONS}

As can be seen from the variables studied, tourism demand has evolved towards greater segmentation, generating clearly differentiated areas within a medium-sized country such as Spain. The new motivations of tourists, related with new trends and the importance of unique sensations promoted by social networking, tend to move away from traditional tourism to a system based on other kind of sensations, this has led to an increase in the number of tourist destinations and the dispersion of the demand through the national geography [11].

The offer must suit the demand in a world that no longer allows all in the name of economy and tourism development, as it can alter the sedimentary and environmental balance of coasts. Qualified development of these areas is fundamental for the proper functioning of one of the productive pillars of the country: "sun and beach" tourism.

The data presented in this paper may serve to reach an approach to tourism concerns, and how the influx of tourists to different areas depends on the services and features they offer, 
so that coastal managers may have the required tools to establish criteria for actions aimed at the proliferation of sustainable and modern tourism.

\section{REFERENCES}

[1] Bertoni, M. \& Ferraro, R., Consideraciones para un turismo sustentable a partir del modelo turístico masivo. Faces, 4(5), pp. 29-43, 1998.

[2] Yepes, V., La explotación de playas. La madurez del sector turístico. O.P. Ingeniería y Territorio, 61, pp. 72-77, 2002.

[3] Domínguez, C.E.R., Domínguez, Á.M.R. \& Domínguez, R.M.R., Análisis de las preferencias del turista hacia un destino turístico maduro. Investigaciones Europeas de Dirección y Economía de la Empresa, 10(2), pp. 131-139, 2004.

[4] Garcia, I., Sebastia, L. \& Onaindia, E., A negotiation approach for group recommendation. Proceedings of the 2009 International Conference on Artificial Intelligence, ICAI, 13-16 Jul. 2009, pp. 919-925, 2009.

[5] Dywer, L. \& Kim, C., Destination competitiveness: a model and determinants. Current Issues in Tourism, 6(5), pp. 369-414, 2003.

[6] Fornés, J.M., la Hera, Á. \& Llamas, M.R., The silent revolution in groundwater intensive use and its influence in Spain. Water Policy, 7(3), pp. 253-268, 2005.

[7] $\mathrm{Hu}, \mathrm{W} . \&$ Wall, G., Environmental management, environmental image and the competitive tourist attraction. Journal of Sustainable Tourism, 13(6), pp. 617-635, 2005.

[8] Hassan, S.S., Determinants of market competitiveness in an environmentally sustainable tourism industry. Journal of Travel Research, 38(3), pp. 239-245, 2000.

[9] Aragonés, L., López, I., Villacampa, Y., Serra, J.C. \& Saval, J., New methodology for the classification of gravel beaches: adjusted on Alicante (Spain). Journal of Coastal Research, 31(4), pp. 1023-1034, 2014.

[10] Ritchie, J.B. \& Crouch, G.I., The Competitive Destination. Cabi: Alberta, Canada, 2003.

[11] Barroso, M.O. \& Flores, D., La competitividad internacional de los destinos turísticos: del enfoque macroeconómico al enfoque estratégico. Cuadernos de Turismo, 17(7), p. 24, 2006. 